\title{
GH administration patterns differently regulate epidermal growth factor signaling
}

\section{María E Díaz, Johanna G Miquet, Soledad P Rossi', Pablo E Irene, Ana I Sotelo, Mónica B Frungieri', Daniel Turyn and Lorena González}

Departamento de Química Biológica, Facultad de Farmacia y Bioquímica, Instituto de Química y Fisicoquímica Biológicas (UBA-CONICET), Universidad de Buenos Aires, Junín 956, 1113 Ciudad de Buenos Aires, Argentina ${ }^{1}$ Instituto de Biología y Medicina Experimental, CONICET, Vuelta de Obligado 2490, 1428 Ciudad de Buenos Aires, Argentina

\author{
Correspondence \\ should be addressed \\ to L González \\ Email \\ Igonzalez@qb.ffyb.uba.ar or \\ Igonza74@yahoo.com.ar
}

\begin{abstract}
Current GH administration protocols imply frequent s.c. injections, resulting in suboptimal compliance. Therefore, there is interest in developing delivery systems for sustained release of the hormone. However, GH has different actions depending on its continuous or pulsatile plasma concentration pattern. GH levels and circulating concentration patterns could be involved in the regulation of epidermal growth factor receptor (EGFR) expression in liver. Aberrant expression of this receptor and/or its hyperactivation has been associated with the pathogenesis of different types of carcinoma. Considering that one of the adverse effects associated with $\mathrm{GH}$ overexpression and chronic use of $\mathrm{GH}$ is the increased incidence of malignancies, the aim of this study was to analyze the effects of $\mathrm{GH}$ plasma concentration patterns on EGFR expression and signaling in livers of mice. For this purpose, GH was administered by s.c. daily injections to produce an intermittent plasma pattern or by osmotic pumps to provoke a continuously elevated GH concentration. Intermittent injections of GH induced upregulation of liver EGFR content, augmented the response to EGF, and the induction of proteins involved in promotion of cell proliferation in female mice. In contrast, continuous GH delivery in male mice was associated with diminished EGFR in liver and decreased EGF-induced signaling and expression of early genes. The results indicate that sustained delivery systems that allow continuous GH plasma patterns would be beneficial in terms of treatment safety with regard to the actions of GH on EGFR signaling and its promitogenic activity.
\end{abstract}

\section{Key Words \\ - growth hormone \\ - epidermal growth factor \\ - intracellular signaling \\ - liver}

Journal of Endocrinology (2014) 221, 309-323

\section{Introduction}

Growth hormone $(\mathrm{GH})$ is a pituitary hormone that stimulates longitudinal bone growth; it induces diverse effects on cell growth and differentiation, and on the metabolism of proteins, lipids, and carbohydrates (Herrington \& Carter-Su 2001). The use of GH in endocrinological practice and for the treatment of various clinical conditions is expanding. The first use of human $\mathrm{GH}$ (hGH) was as replacement therapy in children with GH deficiency (GHD). However, further indications have been gradually approved or proposed since the development of recombinant hGH (rhGH; Kemp \& Frindik 2011, Laron 2011). Current protocols for GH treatment imply its

Published by Bioscientifica Ltd 
s.c. or i.m. injection once daily or three times a week. The main disadvantages of these administration protocols are the short plasma half life of the hormone and its renal toxicity. Moreover, injection results in poor patient compliance, high doses, nonspecific toxicity, and increased cost (Kwak et al. 2009, Park et al. 2013). Thus, development of sustained-release rhGH formulations could improve quality of life and decrease secondary effects (Laron 2011). To date, a once-weekly sustained release GH preparation has been shown to be effective for the treatment of several clinical conditions (Péter et al. 2012, Biller et al. 2013) and sustained delivery systems that last longer are being investigated (Wei et al. 2012, Park et al. 2013). However, GH shows different effects depending on its plasma concentration pattern in many species including mice, rats, and humans (Jansson et al. 1985, Jaffe et al. 2002, Waxman \& O'Connor 2006). Therefore, the efficacy and toxicity of pharmaceutical systems that allow prolonged release of the hormone, which would produce near continuous elevation of circulating $\mathrm{GH}$ levels, should be assessed and compared with the effects of the treatments that involve intermittent injections and mimic a pulsatile concentration pattern.

The differential effects of intermittent and sustained plasma GH patterns have been studied in humans and animals, mostly focusing on the consequences for on longitudinal growth and metabolism; however, the differential effects of plasma GH patterns on the activation of signaling pathways involved in cell proliferation and survival have not been analyzed. A relevant side effect associated with chronic use of GH and its overexpression is the increased risk of malignancies (Jenkins 2006, Siobhan \& Shereen 2008, Laron 2011). Previous studies indicates that GH concentration patterns regulate epidermal growth factor receptor (EGFR) expression in rodent liver. The EGFR, also known as ERBB1, is a plasma membrane glycoprotein which belongs to the ERBB family of receptor tyrosine kinases (Burgess 2008). Upon ligand binding, ERBB proteins homo- or heterodimerize with other members of the ERBB family to activate downstream signaling pathways that regulate proliferation, growth, and differentiation (Riese \& Stern 1998). Aberrant expression of the EGFR and/or hyperactivation of this receptor have been associated with the pathogenesis and progression of different types of cancers (Ito et al. 2001, Normanno et al. 2006). GH has been shown to modulate the expression of Egfr in the liver (Jansson et al. 1988, González et al. 2010). Egfr mRNA levels and EGF binding to liver were reported to be more efficiently induced by a pulsatile pattern of plasma GH concentration (Jansson et al. 1988, Ekberg et al. 1989, Kashimata et al. 1989). However, results of these studies are controversial since other authors found no differences on the induction of Egfr mRNA or EGF binding when the hormone was administered by intermittent injections or continuous infusion to hypophysectomized rats (Johansson et al. 1989). Moreover, we have recently demonstrated that transgenic mice overexpressing GH, which exhibit a continuous plasma GH expression pattern (Norstedt \& Palmiter 1984), show increased EGFR expression (Miquet et al. 2008, González et al. 2010).

While studies regarding GH concentration patterns and EGFR expression in the liver have been performed, the resulting effects on EGFR signaling have not been analyzed. Increased EGFR liver content does not necessarily imply the upregulation of EGF signaling. Actually, transgenic mice overexpressing GH showed elevated EGFR protein levels in the liver, but activation upon ligand stimulation was diminished for some of its signaling cascades (González et al. 2010, Díaz et al. 2012).

Therefore, considering the growing interest in the development of sustained delivery systems for GH administration, the potential oncogenic properties of this hormone and its likely dimorphic regulation of a receptor widely involved in cancer, the EGFR, the aim of this study was to analyze the effects of different GH administration protocols on EGFR expression, signaling, and induction of mitogenic mediators in the liver for normal mice.

\section{Subjects and methods}

\section{Reagents}

Highly purified porcine GH (pGH) was obtained from Zamira Life Sciences Pty Ltd (Knoxfield, VIC, Australia). Recombinant human EGF was obtained from Sigma Chemical Co. PVDF membranes, high-performance chemiluminescence film, and ECL-Plus were from Amersham Biosciences. Acrylamide, bis-acrylamide, and tetramethylethylenediamine (TEMED) were obtained from Bio-Rad Laboratories. Secondary antibodies conjugated with HRP, anti-major urinary proteins (MUPs), anti-EGFR, anticytokine-inducible SH2-domain-containing protein (CIS), and anti-signal transducer and activator of transcription 5 (STAT5) antibodies were purchased from Santa Cruz Biotechnology Laboratories. The anti-phospho-STAT5a/b Tyr694/699 antibody was from Millipore (Billerica, MA, USA). The anti-phospho-AKT Ser473, anti-AKT,

Published by Bioscientifica Ltd. 
anti-p44/42 MAPK (anti-ERK1/2), anti-phospho-p44/42 MAPK Thr202/Tyr204 (anti-phospho-ERK1/2), anti-phospho-STAT3 Tyr705, anti-phospho-EGFR Tyr845, anticMyc, and anti-cFos antibodies were from Cell Signaling Technology, Inc. (Beverly, MA, USA). The bicinchoninic acid (BCA) protein assay kit was obtained from Thermo Scientific, Pierce Protein Research Products (Rockford, IL, USA). All other chemicals were of reagent grade.

\section{Animals}

Swiss-Webster female and male adult animals (3-4 months old, body weight: $26-30 \mathrm{~g}$ ) were used. The mice were housed three to five per cage in a room with controlled light ( $12 \mathrm{~h}$ light: $12 \mathrm{~h}$ darkness cycle) and temperature $\left(22 \pm 2^{\circ} \mathrm{C}\right)$. Sentinel animals were tested for all major murine pathogens and the results of the tests were uniformly negative. The animals had free access to a nutritionally balanced diet and tap water. The appropriateness of the experimental procedure, the required number of animals used, and the method of acquisition were in compliance with federal and local laws, and with institutional regulations.

\section{Animal treatments}

GH-treatment The hormone was administered to Swiss-Webster mice for 5 days under two different protocols: i) s.c. injections of $\mathrm{pGH}(0.5 \mu \mathrm{g} / \mathrm{g}$ of body weight) twice a day and ii) s.c. continuous infusion with an osmotic minipump (model 1007D, Alzet) delivering the hormone at a dose $1 \mu \mathrm{g} / \mathrm{g}$ of body weight per day (Jansson et al. 1988, Karlsson et al. 1999). Protocols for GH treatment were adapted from previously described techniques (Jansson et al. 1988, Ekberg et al. 1989). Control animals for each group were treated in a similar fashion but saline solution was administered instead.

Acute EGF stimulation Mice were fasted for $6 \mathrm{~h}$ before receiving an i.p. injection of recombinant human EGF at $2 \mathrm{mg} / \mathrm{kg} \mathrm{BW}$ in $0.9 \% \mathrm{w} / \mathrm{v} \mathrm{NaCl}$. Animals were killed 10 min after administration of EGF (González et al. 2010) to study the phosphorylation of EGF signaling mediators, or after $30 \mathrm{~min}$ or $1 \mathrm{~h}$ to study the expression of early genes involved in the induction of cell cycle progression. Control mice received injections of saline solution to evaluate basal conditions. Urine was collected at the time the animals were killed and the livers were removed and stored frozen at $-70^{\circ} \mathrm{C}$ until homogenization.

\section{Processing of urine samples}

Urine samples were processed immediately after being obtained. They were centrifuged at $8800 \boldsymbol{g}$ for $3 \mathrm{~min}$ at $4{ }^{\circ} \mathrm{C}$. The supernatant was recovered and diluted at a ratio of $1: 3$ in $0.06 \mathrm{~mol} / 1$ Tris, $0.001 \mathrm{~mol} / 1$ EDTA (pH 7.4) buffer. An aliquot of each sample was diluted in Laemmli buffer, boiled for $5 \mathrm{~min}$, and stored at $-20^{\circ} \mathrm{C}$ until used for electrophoresis. The samples were subjected to SDS-PAGE using Bio-Rad Mini Protean apparatus (Bio-Rad Laboratories). Gels were stained with Coomasie Blue.

\section{Preparation of liver extracts}

Liver samples were homogenized at the ratio $0.1 \mathrm{~g} / \mathrm{ml}$ as previously described (González et al. 2010, Díaz et al. 2012). Protein concentrations of supernatants were determined using a BCA protein assay kit and samples were prepared for immunoblotting (González et al. 2010, Díaz et al. 2012). For immunoprecipitation, aliquots of solubilized liver containing $4 \mathrm{mg}$ of protein were incubated overnight at $4{ }^{\circ} \mathrm{C}$ with anti-CIS antibody and subsequently processed as described previously (González et al. 2010).

\section{Immunoblotting}

Samples were subjected to SDS-PAGE. Electrotransference of proteins from gel to PVDF membranes, incubation with antibodies, reprobing, detection, and quantification of band intensity were carried out as described previously (González et al. 2010, Díaz et al. 2012).

\section{RNA isolation and quantitative RT-PCR}

Total RNA from $50 \mathrm{mg}$ liver tissue was extracted with TRIzol reagent (Life Technologies) according to the manufacturer's instructions. The purity of RNA was assessed from the ratio of the optical densities at 260 and $280 \mathrm{~nm}$, and the integrity was controlled by electrophoresis on $1 \%$ agarose gel. Total RNA $(2 \mu \mathrm{g})$ were used for the RT reaction in a $20 \mu \mathrm{l}$ volume using M-MLV reverse transcriptase (Promega, $200 \mathrm{U} / \mu \mathrm{l}$ ) and random hexamer primers (Biodynamics SRL, Buenos Aires, Argentina) (Frungieri et al. 2002).

For quantitative real-time PCR, cDNA was amplified using an ABI PRISM 7700 Sequence Detection System (Applied Biosystems), using SYBR Green Master Mix Reagent (Applied Biosystems). The forward (F) and reverse (R) primers used were as follows: EGFR: F, ATAGTGGTGGTGGCCCTTGG and R, GAGGTTCCACGAGCTCTCTCT;

Published by Bioscientifica Ltd 
$c M y c$ : F, TCACCAGCACAACTACGCCG and R, TGCTTCAGGACCCTGCCACT; cFos: F, CCGACTACGAGGCGTCATCC and R, CTGCGCAAAAGTCCTGTGTGT; and cyclophilin A: F, GCGTCTCCTTCGAGCTGTT and $\mathrm{R}$, AAGTCACCACCCTGGCAC. Cyclophilin A was chosen as the housekeeping gene. Reaction data were collected and analyzed using the complementary computer software (Sequence Detection Software, Applied Biosystems, version 1.3). For the assessment of quantitative differences in the cDNA target between samples, the mathematical model of Pfaffl (2001) was applied. An expression ratio was determined for each sample by calculating (Etarget) ${ }^{\Delta C \mathrm{t}(\text { target })} /(E \text { cyclophilin })^{\Delta C \mathrm{t}(\text { cyclophilin) }}$, where $E$ is the efficiency of the primer set and $\Delta C \mathrm{t}=$ $\left.C \mathrm{t}_{\text {(normalization } \mathrm{cDNA})}-\mathrm{Ct}_{\text {(experimental }} \mathrm{cDNA}\right)$. The amplification efficiency of each primer set was calculated from the slope of a standard amplification curve of log microliters of cDNA per reaction vs $C \mathrm{t}$ value $\left(E=10^{-(1 / \text { slope })}\right)$. Efficiencies of $2 \pm 0.1$ were considered optimal.

\section{Statistical analysis}

Experiments were carried out analyzing all groups of animals in parallel, $n$ representing the number of different individuals used in each group. Results are presented as mean \pm s.E.M. of the number of samples indicated. Statistical analyses were performed by ANOVA followed by the Newman-Keuls multiple comparison test using the GraphPad Prism 4 statistical program by GraphPad Software, Inc. (San Diego, CA, USA). Student's t-test was used when only two groups were analyzed. Data were considered significantly different if $P<0.05$.

\section{Results}

\section{Effects of different GH administration protocols on the expression of proteins regulated by plasma GH concentration patterns}

Previous studies have demonstrated that intermittent injections and continuous administration of GH produce different plasma concentrations patterns of the hormone and effects; however, those studies were carried out in hypophysectomized animals (Jansson et al. 1988, Ekberg et al. 1989, Waxman et al. 1991). In the present study, nonhypophysectomized mice were studied. In normal rodents, as it occurs in several species, GH secretion is sexually dimorphic (Jansson et al. 1985, MacLeod et al. 1991, Veldhuis \& Bowers 2003). A key difference between male and female GH profiles is the sustained interpulse interval with little or no detectable circulating GH characteristic of adult males (Jansson et al. 1985, MacLeod et al. 1991, Jaffe et al. 1998). Normal female and male mice also have a different endocrine and metabolic background. To study the effects of different GH concentration patterns in normal mice, supraphysiological GH doses were exogenously administered in an intermittent or continuous fashion. Then, the expression of proteins regulated by the GH plasma concentration patterns was assessed in order to establish a relationship between the GH administration protocols and the GH plasma concentration patterns produced by the treatments. For this purpose, MUPs and CIS in the liver and concentrations of MUPs in the urine were determined in GH-treated and control mice.

The MUPs are acidic protein isoforms with molecular masses of between 19 and $21 \mathrm{kDa}$ (Cavaggioni \& Mucignat-Caretta 2000). These pheromone-binding proteins are synthesized in the liver and released through the kidney into the urine. The secretory pattern of GH regulates the expression MUP genes; induction of MUP mRNAs requires pulsatile occupancy of GH receptors, while continuous GH concentration pattern represses expression of MUP genes (Norstedt \& Palmiter 1984, Johnson et al. 1995). To show the difference in hepatic contents of MUPs between male and female mice, samples from mice of both sexes were analyzed in parallel (Supplementary Fig. 1A, see section on supplementary data given at the end of this article). Intermittent administration of GH to female mice produced an increase in MUPs in liver (Fig. 1A); however, this GH administration protocol had no effect on expression of MUPs in male mice (Fig. 1B). In contrast, continuous administration of the hormone had no effect on expression of MUPs in the liver of female mice (Fig. 1C), but caused a decrease in the level MUPs in the liver of male mice (Fig. 1D). To confirm the effects of exogenously administered GH on production of MUPs, the concentration of these proteins in urine was determined. Consistent with the results obtained for MUPs in liver, the concentrations of MUPs in urine increased in female mice that received intermittent injections of GH (Fig. 1E) but diminished in male mice that received continuous administration of the hormone (Fig. 1F). The absence of effects on expression of MUPs expression observed in male mice that received injections of GH could be explained by the already high levels of MUPs induced by the endogenous secretion pattern of the hormone. In the case of female mice, no effects on expression of MUPs were found in animals treated with GH delivered by the osmotic pumps because expression of MUPs is already low.

Published by Bioscientifica Ltd. 

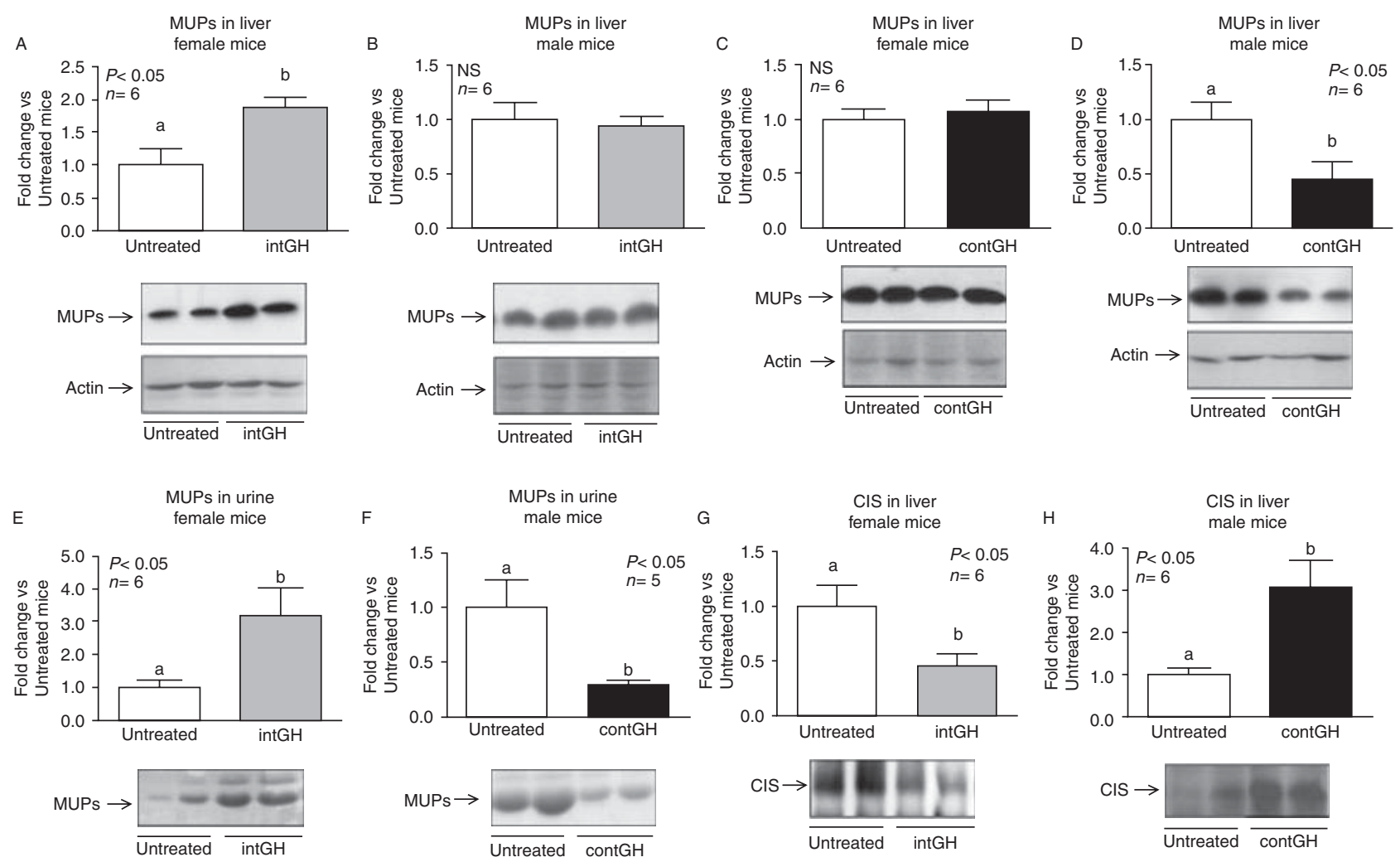

Figure 1

Levels of MUPs and CIS in liver and concentrations of MUPs in urine in $\mathrm{GH}$-treated and control mice. Solubilized liver samples from female and male mice treated with intermittent injections of $\mathrm{GH}$ (intGH) or continuous delivery of GH (contGH) and their respective controls were subjected to immunoblotting analysis to determine the hepatic levels of MUPs (21 kDa) (A, B, C and $D$ ). Reprobing with anti-actin antibody demonstrated similar protein loading for all lanes. Urine samples from female mice treated with intGH, male mice receiving cont $\mathrm{GH}$, and their respective controls were analyzed by

The liver content of the suppressor of cytokine signaling CIS also varies depending on GH plasma concentration patterns (Karlsson et al. 1999). CIS is induced by a continuous pattern of GH concentration (Ram \& Waxman 2000). Consequently, its expression decreased in female mice that received intermittent injections of $\mathrm{GH}$ compared with controls (Fig. 1G), but increased in male mice administered GH in a continuous manner compared with untreated male mice (Fig. 1H). A tendency towards decreased CIS levels was also evidenced when GH was administered by intermittent injections to male mice; however, the difference was not significant (Supplementary Fig. 1B). Continuous administration of GH to female mice induced a slight and non-significant increase in hepatic levels of CIS (Supplementary Fig. 1C).

Therefore, a pulsatile pattern of GH concentration was evident in female mice exogenously treated with intermittent injections of $\mathrm{GH}$, while a continuous pattern

SDS-PAGE to assess concentrations of MUPs in urine ( $E$ and F). CIS (32 kDa) was immunoprecipitated from solubilized livers from female and male mice that received intGH or contGH treatment, respectively, and assessed by immunoblotting with anti-CIS ( $\mathrm{G}$ and $\mathrm{H}$ ). Quantification was performed by scanning densitometry and expressed as fold change vs values measured for $\mathrm{GH}$-untreated normal mice. Data are the mean \pm S.E.M. of the indicated number of subsets $(n)$ of individual animals. Different letters denote significant differences $(P \leq 0.05)$. Representative western blots are shown.

of circulating levels of GH was demonstrated to be caused by sustained delivery of GH in male mice. For this reason, the effects of pulsatile GH plasma concentration patterns on EGFR expression and signaling were studied in female mice that received intermittent injections of GH or saline solution. On the other hand, the effects of constant elevated concentrations of the hormone were analyzed in male mice by implantation of sustained delivery systems for continuous release of the hormone or saline solution. In addition, control assays involving intermittent administration of GH to male mice and continuous delivery of the hormone to female mice were carried out.

EGFR expression, activation, and signaling vary with the pattern of plasma GH concentrations

The effects of plasma GH patterns on hepatic Egfr mRNA levels and EGFR protein content were determined in the

Published by Bioscientifica Ltd 
livers of female mice that received intermittent treatment with GH and in the livers of male mice that received continuous administration of the hormone (Fig. 2 A, B, C and D). Egfr mRNA levels increased in the livers of mice that received intermittent GH injections, but results were not significantly different from those for untreated mice (Fig. 2A). In contrast, administration of GH by osmotic pumps provoked a decline in Egfr mRNA levels (Fig. 2B). EGFR protein content was analyzed in solubilized livers of GH-treated and control mice that subsequently received acute stimulation with EGF. Immunoblotting analysis showed that the protein content of EGFR was significantly increased by a pulsatile plasma GH pattern (Fig. 2C), while continuous circulating levels of GH decreased EGFR protein abundance (Fig. 2D) in accordance with results for the determination of $E g f r$ mRNA.

Ligand-induced EGFR dimerization leads to receptor autophosphorylation at tyrosine residues. Phosphotyrosine residues allow the recruitment of specific partners to activate different downstream pathways, including
Ras/MAPK, PI3K/Akt, and STAT pathways (Wells 1999, Henson \& Gibson 2006, Normanno et al. 2006). EGFR is augmented in transgenic mice overexpressing $\mathrm{GH}$; however, this does not result in an increased response to EGF (González et al. 2010). To ascertain the effects of the different GH plasma patterns on EGF-induced EGFR activation, EGFR phosphorylation on Tyr845 in the livers of GH-treated and untreated mice after acute stimulation with EGF was assessed (Fig. 2E and F). In accordance with the changes described for hepatic EGFR content, EGF-induced receptor phosphorylation levels increased in mice that received s.c. injections of $\mathrm{GH}$ compared with untreated mice (Fig. 2E), but decreased in mice that received continuous administration of GH with respect to their controls (Fig. 2F). The analysis of the ratio between EGFR phosphorylation levels and EGFR content of liver revealed that increased or decreased EGFR phosphorylation levels could be attributed to the augmented or reduced amount of hepatic protein respectively (Fig. $2 \mathrm{G}$ and $\mathrm{H}$ ).
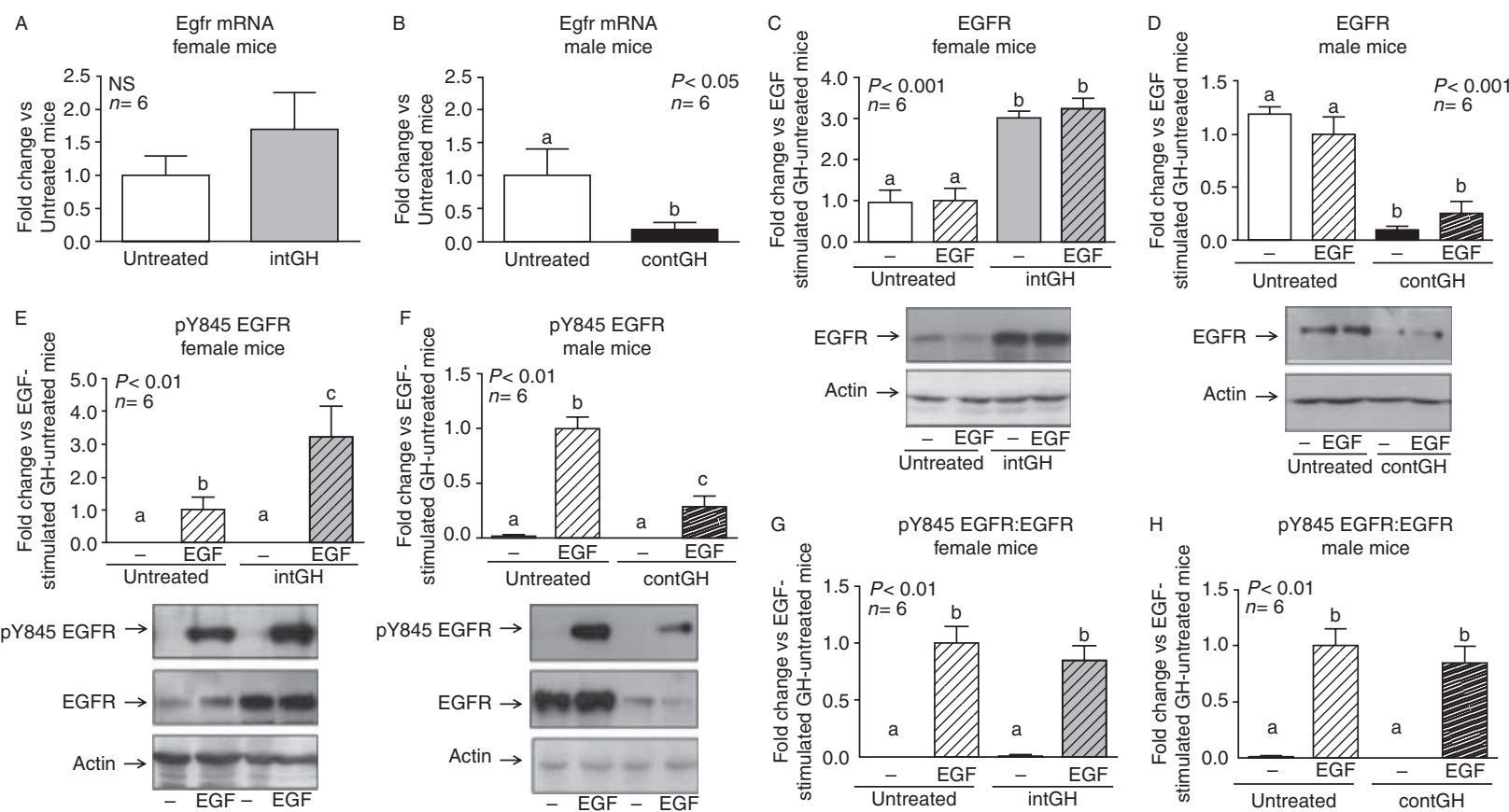

Figure 2

Hepatic Egfr mRNA expression, protein content, and phosphorylation. Liver samples from female mice treated with intermittent injections of $\mathrm{GH}$ (intGH), male mice receiving continuous delivery of $\mathrm{GH}$ (contGH), and their respective controls were analyzed by qRT-PCR to determine Egfr mRNA levels (A and B). Solubilized livers from $\mathrm{GH}$-treated and control mice that subsequently received acute stimulation with EGF for $10 \mathrm{~min}$ (EGF) or not (-) were subjected to immunoblot analysis to determine liver EGFR ( $170 \mathrm{kDa})$ content $(C$ and $\mathrm{D})$ and EGFR Tyr845 phosphorylation levels ( $E$ and F). Membranes were reprobed to

asses actin content and to demonstrate uniform protein loading for all lanes. Immunoblots were scanned and quantification was performed by densitometry. Data resulting from quantification analyses were used to calculate the pY845 EGFR:EGFR ratio ( $G$ and $H$ ). Results were expressed as fold change vs values measured for untreated normal mice (A and $B$ ) or EGF-stimulated GH-untreated mice (C, D, E, F, G and H). Data are the mean \pm s.E.M. of the indicated number of subsets $(n)$ of individual animals. Different letters denote significant differences $(P \leq 0.05)$. Representative western blots are shown. 
The MAPKs Erk1 and Erk2 have been extensively associated with the promotion of cell proliferation. To ascertain the effects of different plasma GH concentration patterns on the regulation of EGF-induced Erk1/2 activation, Erk1/2 phosphorylation in the livers of mice that received intermittent or sustained administration of $\mathrm{GH}$ followed by the acute stimulation with EGF or saline was determined. In accordance with the results described for
EGFR, phosphorylation levels of Erk1/2 were increased in female mice treated with $\mathrm{GH}$ injections compared with untreated mice (Fig. 3A), but decreased in the livers of male mice that received continuous administration of GH (Fig. 3B). No differences in the protein levels of Erk1/2 were observed for any of the treatments (Fig. 3A and B).

The activation of EGFR also results in phosphorylation of Akt at its two main and activating phosphorylation
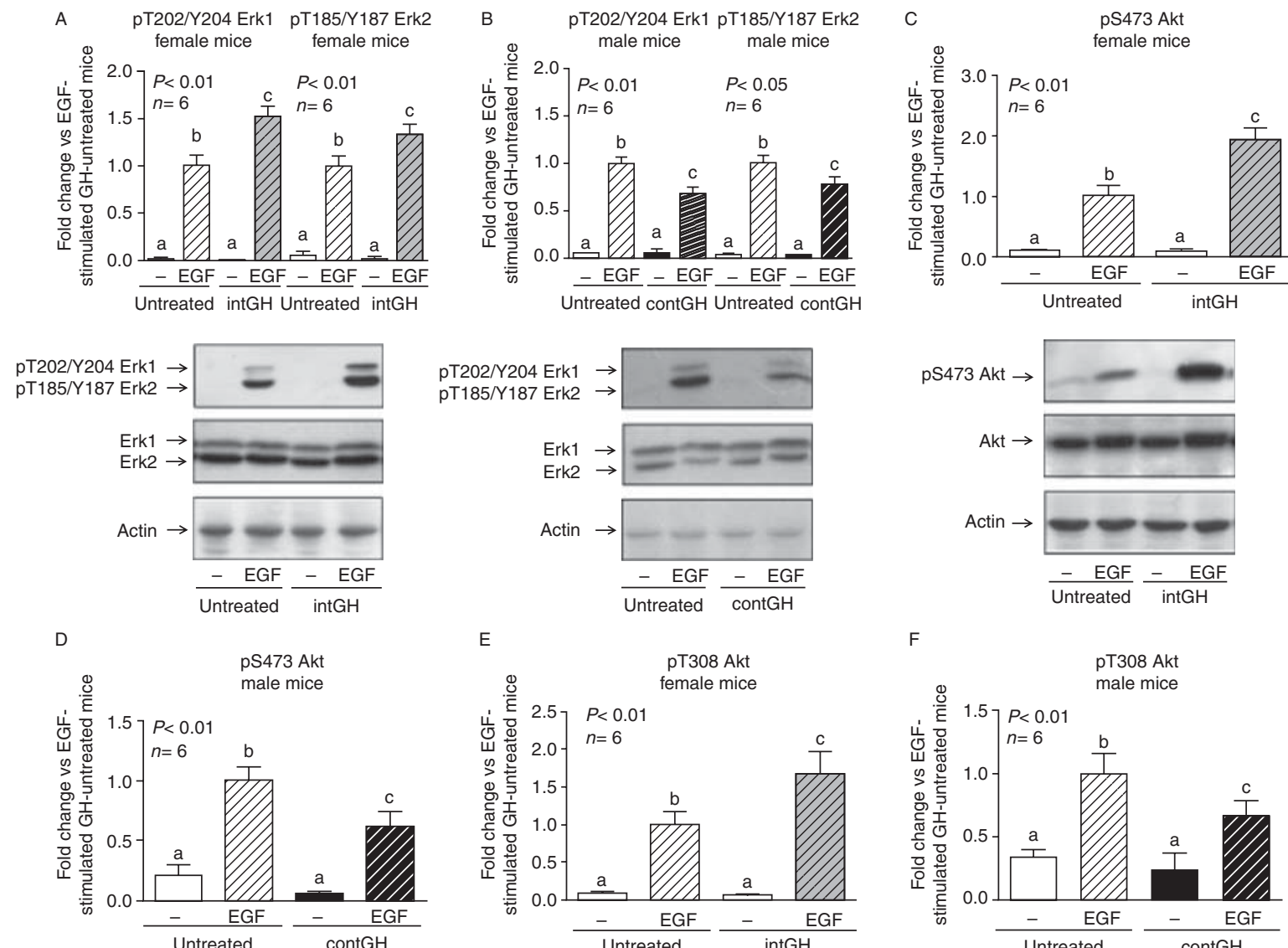

E

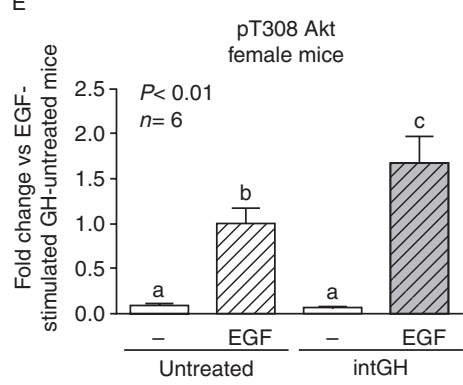

$\mathrm{F}$
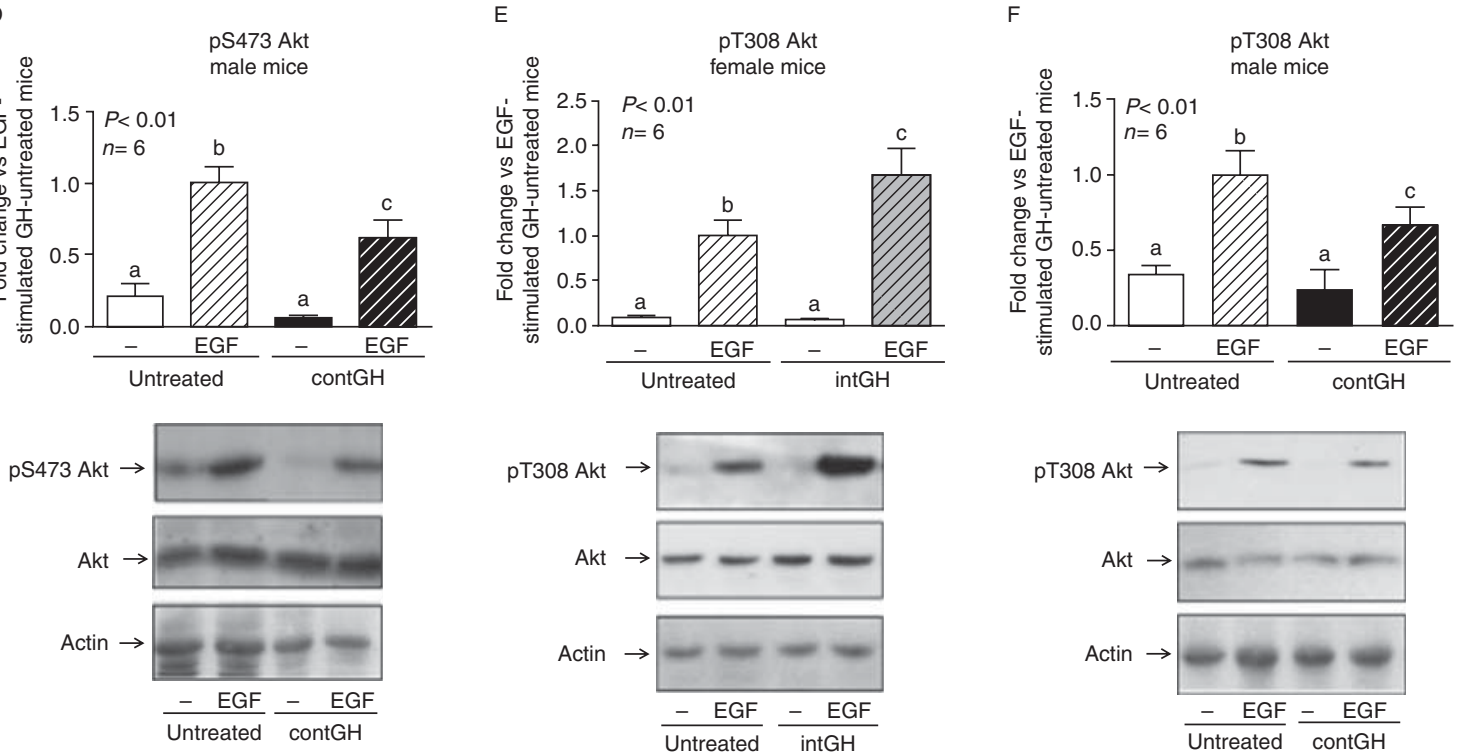

\section{Figure 3}

Hepatic Erk1/2 and Akt phosphorylation and protein content. Solubilized liver from female mice treated with intermittent injections of $\mathrm{GH}$ (intGH), male mice receiving continuous infusion of $\mathrm{GH}$ (contGH), and their respective controls that subsequently received acute stimulation with EGF for $10 \mathrm{~min}$ (EGF) or not $(-)$ were subjected to immunoblot analysis to determine Erk1/2 (44/42 kDa) phosphorylation levels and protein content (A and B); Akt (62 kDa) phosphorylation levels at Ser473 (C and D), and at
Thr308 (E and F) and its protein content (C, D, E and F). Reprobing with anti-actin antibody demonstrated equal protein loading for all lanes. Quantification was performed by scanning densitometry and expressed as fold change vs EGF-stimulated GH-untreated mice. Data are the mean \pm S.E.M. of the indicated number of subsets $(n)$ of individual animals. Different letters denote significant differences $(P \leq 0.05)$. Representative western blots are shown. 
sites, Thr308 in the kinase domain and Ser473 in the C-terminal regulatory domain (Fresno Vara et al. 2004, Osaki et al. 2004). Once activated, Akt promotes cell survival and proliferation. Akt protein content and phosphorylation of its activating residues in the livers of mice that received intermittent or sustained administration of GH (Fig. 3C, D, E and F). In accordance with the results recorded for Erk1/2, Akt activation was augmented in the livers of female mice that received intermittent administration of GH (Fig. 3C and E), but was diminished in the livers of male mice that received the hormone in a continuous fashion (Fig. 3D and F). The protein abundance of the kinase did not significantly vary after the different GH treatments (Fig. 3C, D, E and F).

EGFR activation also results in activation of STATs (Guren et al. 2003, Quesnelle et al. 2007), which has been associated with development and progression of many malignancies (Buettner et al. 2002, Quesnelle et al. 2007). EGF-induced STAT3 phosphorylation in mice that received the different GH administration protocols was compared with the results for the respective untreated control mice (Fig. 4). In accordance with the findings described for Erk1/2 and Akt activation, EGF-induced STAT3 phosphorylation increased in the presence of a pulsatile $\mathrm{GH}$ concentration pattern (Fig. 4A), whereas it was diminished when the GH plasma concentration pattern was continuous (Fig. 4B). However, protein content was not modified in response to the different $\mathrm{GH}$ administration protocols (Fig. 4A and B). Similar results were found for STAT5 activation when EGF-induced phosphorylation and protein levels were studied in mice that received GH treatments and in their respective controls (Fig. 4C and D).

EGFR protein levels and EGF-induced activation of Erk1/2 and Akt were also determined, as a control, in female mice that received continuous administration of $\mathrm{GH}$ and in male mice that received intermittent doses of the hormone by injection. Continuous administration of GH to female mice had no effects on liver EGFR content, while GH injections induced a slight but non-significant increase in hepatic EGFR content (Fig. 5A and B). In accordance with the absence of effects on EGFR levels, neither continuous administration of $\mathrm{GH}$ to female mice nor intermittent injection of GH into normal male mice induced changes in Erk1/2 or Akt phosphorylation levels in response to EGF (Fig. 5C, D, E and F). The absence of effects of $\mathrm{GH}$ administered by the osmotic pumps to female mice on EGFR expression and EGF signaling correlates with the lack of effects of the treatment observed for expression of MUPs (Fig. 1C). Similarly, intermittent GH injections to male mice had no effects on hepatic levels of EGFR and EGF signaling as well as on expression of MUPs (Fig. 1B). In both cases, exogenous administration of GH does not seem to induce a net change with respect to endogenous GH concentration patterns.
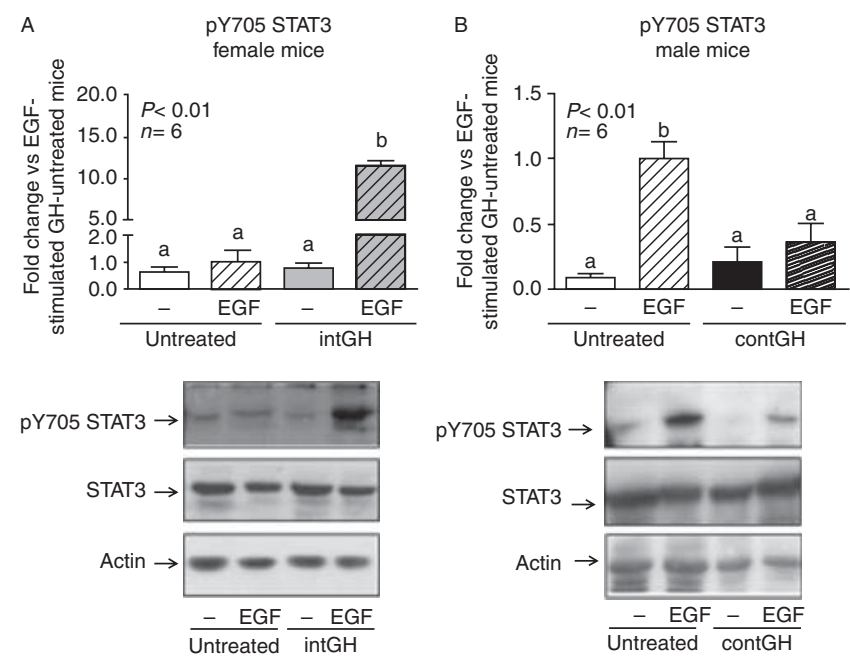
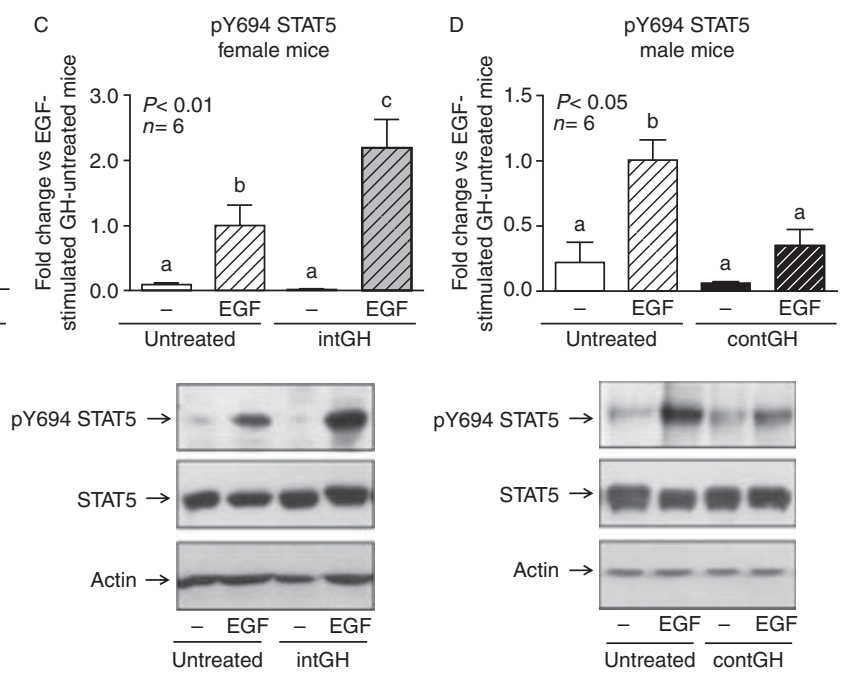

\section{Figure 4}

STAT3 and STAT5 phosphorylation and protein content in the liver. Solubilized livers from female mice treated with intermittent injections of GH (intGH), male mice that received continuous delivery of $\mathrm{GH}$ (contGH), and their respective controls that subsequently received acute stimulation with EGF for $10 \mathrm{~min}$ (EGF) or not $(-)$ were subjected to immunoblot analysis to determine phosphorylation levels of STAT3 (86-91 kDa) (A and B) and STAT5 (92 kDa)
( $C$ and $D$ ) as well as their protein contents ( $A, B, C$ and D). Reprobing with anti-actin antibody demonstrated uniform protein loading for all lanes. Quantification was performed byscanning densitometry and expressed as fold change vs EGF-stimulated GH-untreated mice. Data are the mean \pm s.E.M. of the indicated number of subsets $(n)$ of individual animals. Different letters denote significant differences $(P \leq 0.05)$. Representative western blots are shown.

Published by Bioscientifica Ltd. 
The pattern of plasma GH concentrations affects EGF induction of proteins involved in cell cycle promotion

As a consequence of cellular stimulation with several mitogenic signals, including the EGF, $c M y c$ expression and activation are induced mainly via the MAPK/ERK pathway (Curran et al. 1985). Considering the differential effects on EGFR expression and signaling observed in mice treated with intermittent injections of GH or with a sustained delivery system for GH administration, $c M y c$ induction upon EGF stimulation was assessed to elucidate the possible differential effects of plasma GH concentration patterns on EGF-induced proliferation in liver. For this purpose, the kinetics of $c M y c$ mRNA and protein expression upon exogenous administration of EGF for different times
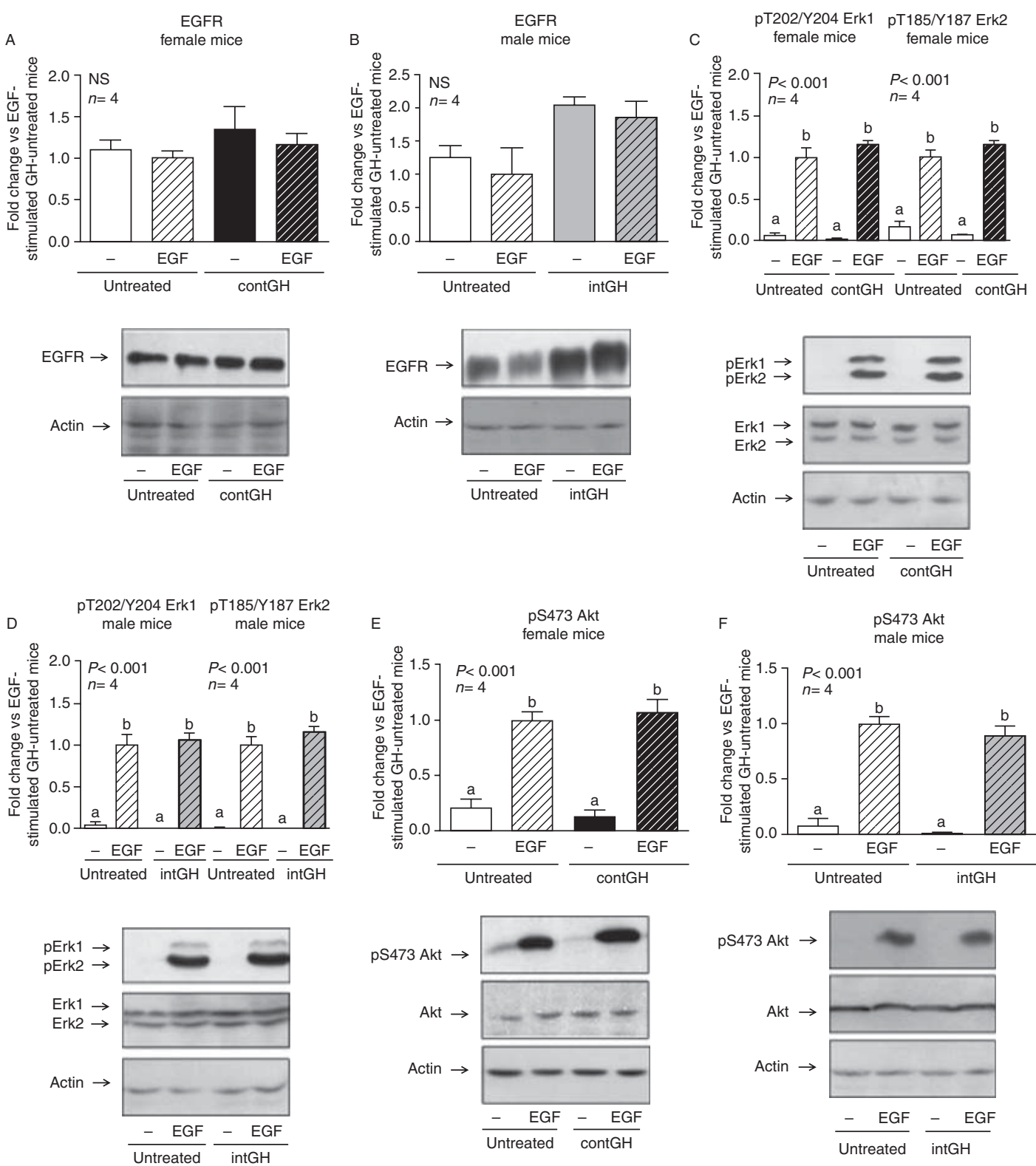

Figure 5

Hepatic EGFR content, Erk1/2, and Akt phosphorylation and protein detection. Solubilized livers from female mice receiving continuous delivery of $\mathrm{GH}$ (contGH), male mice treated with intermittent injections of $\mathrm{GH}$ (intGH), and their respective controls which subsequently received acute stimulation with EGF for 10 min (EGF) or not (-) were analyzed by immunoblotting to determine EGFR protein levels (A and B), Erk1/2 and Akt phosphorylation, and protein content (C, D, E and F). Membranes were reprobed to asses actin content and demonstrate equal protein loading for all lanes. Quantification was performed by scanning densitometry and expressed as fold change vs EGF-stimulated GH-untreated mice. Data are the mean + s.E.M. of the indicated number of subsets $(n)$ of individual animals. Different letters denote significant differences $(P \leq 0.05)$. Representative western blots are shown. 
were first evaluated in the liver of female and male mice with no GH treatment. No sex differences were observed, both mRNA and protein expression showed maximal induction $1 \mathrm{~h}$ after EGF injection (Fig. 6A and B); therefore, this time period was selected for evaluation of the effects of different GH concentration patterns. In accordance with variations described for EGFR expression and signaling, EGF-induced $c M y c$ mRNA and protein content were increased by the pulsatile $\mathrm{GH}$ concentration pattern induced in female mice by GH injections (Fig. 6C and E) whereas they were decreased by the continuous $\mathrm{GH}$ concentration pattern provoked by sustained delivery of the hormone in male mice (Fig. 6D and F).

EGF-induced expression of the oncogene $c F$ os was also analyzed in the livers of mice that received GH by different modes of administration. The kinetics of cFos transcription and transduction upon EGF stimulation were first assessed in the livers of non-GH treated female and male mice. cFos mRNA levels reached a maximum 30 min after EGF injection, while protein content attained higher levels $1 \mathrm{~h}$ after EGF administration (Fig. 7A and B) in both sexes. Considering the data from kinetic studies, $c F o s$ mRNA and protein content in the livers of untreated and GH-treated mice, under basal conditions and after acute stimulation with EGF, were measured. In accordance with previous results, both hepatic cFos mRNA and protein levels were increased by the pulsatile GH concentration pattern (Fig. 7C and E) whereas they were decreased by the continuous plasma GH pattern (Fig. 7D and F).

\section{Discussion}

Currently, there is increasing interest in developing delivery systems that allow sustained release of GH to
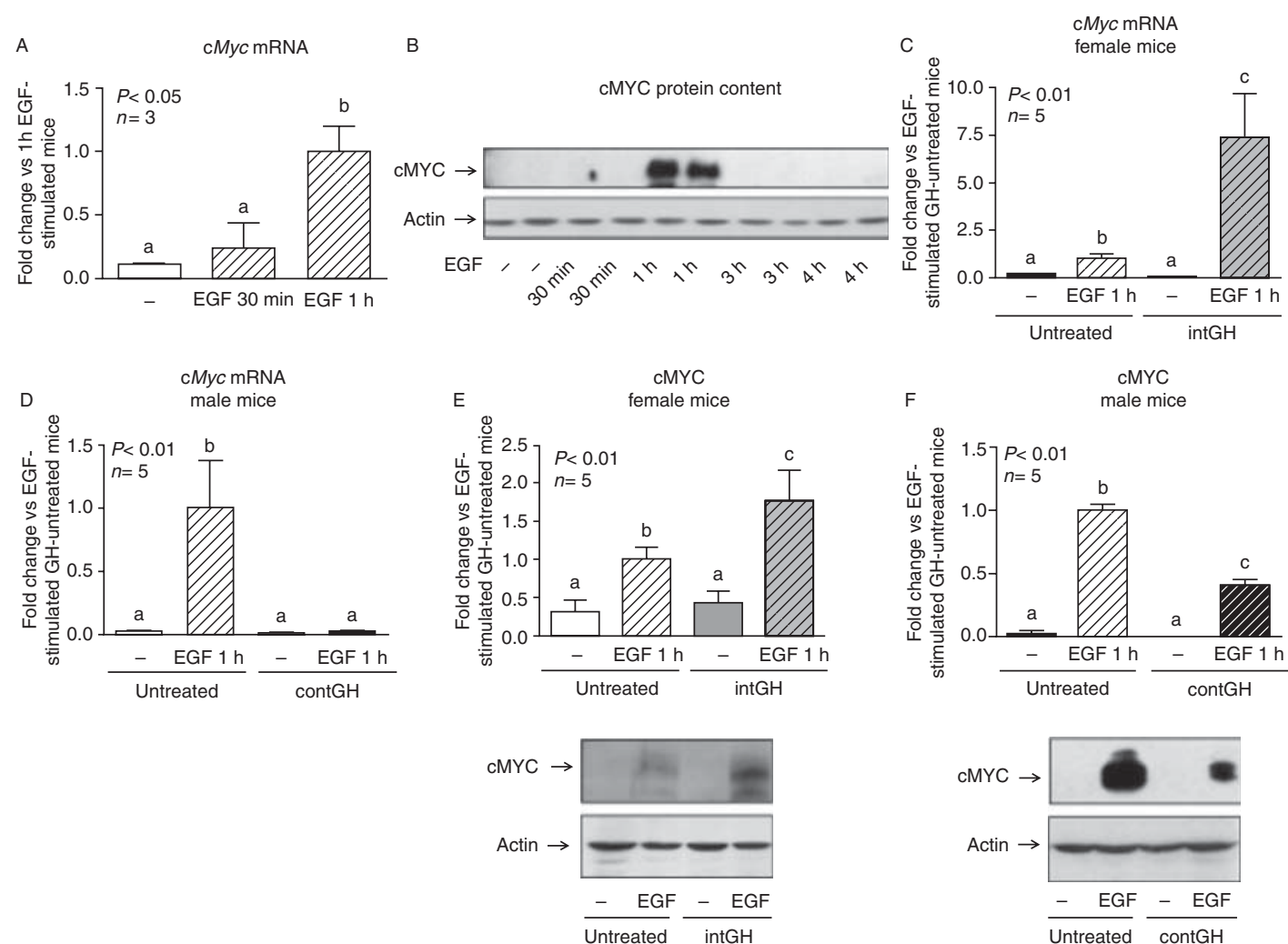

\section{Figure 6}

Hepatic cMyc expression and protein content. Liver samples from mice stimulated with EGF over different time periods or not stimulated were analyzed by qRT-PCR and immunoblotting to determine cMyc expression and its protein content induction respectively ( $A$ and $B)$. CMYC (67 kDa) expression was analyzed by qRT-PCR in female mice treated with intermittent injections of $\mathrm{GH}$ (intGH), male mice receiving continuous infusion of $\mathrm{GH}$ (contGH) and their respective controls that received acute stimulation with EGF for $1 \mathrm{~h}$ (EGF $1 \mathrm{~h}$ ) or not $(-)$ (C and D). Protein contents of liver samples were analyzed by immunoblotting for $\mathrm{GH}$-treated and control mice that received acute stimulation with EGF for $1 \mathrm{~h}$ (EGF $1 \mathrm{~h}$ ) or not $(-)$ (E and F). Reprobing with anti-actin antibody demonstrated equal protein loading in all lanes. Immunoblots were scanned and quantification was performed by densitometry. Results were expressed as fold change vs values measured for EGF-stimulated GH-untreated mice (A, C, D, E and F). Data are the mean \pm S.E.M. of the indicated number of subsets $(n)$ of individual animals. Different letters denote significant differences $(P \leq 0.05)$. Representative western blots are shown. http://joe.endocrinology-journals.org DOI: 10.1530/JOE-13-0447
(C) 2014 Society for Endocrinology Printed in Great Britain
Published by Bioscientifica Ltd 
A
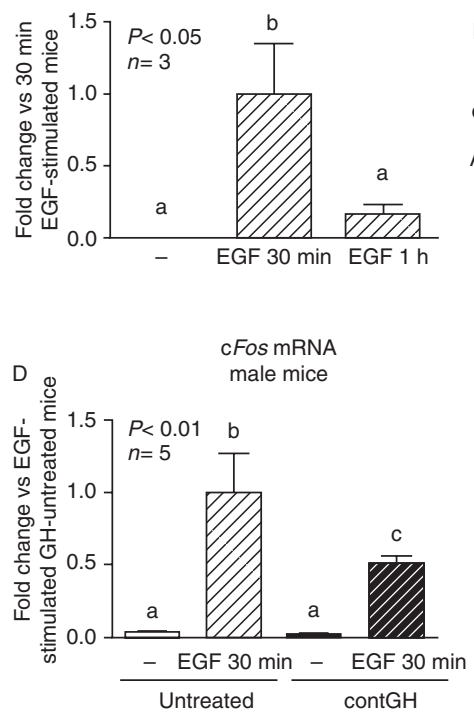
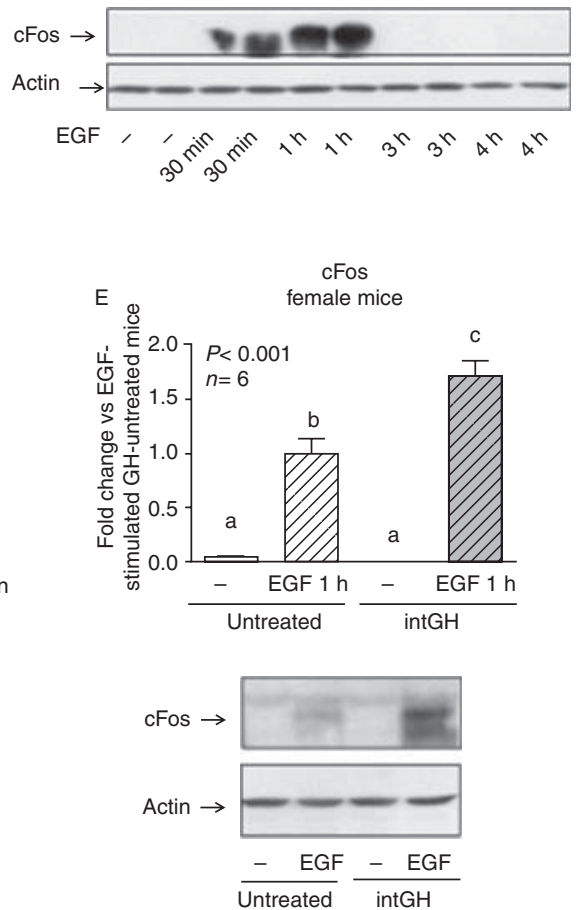
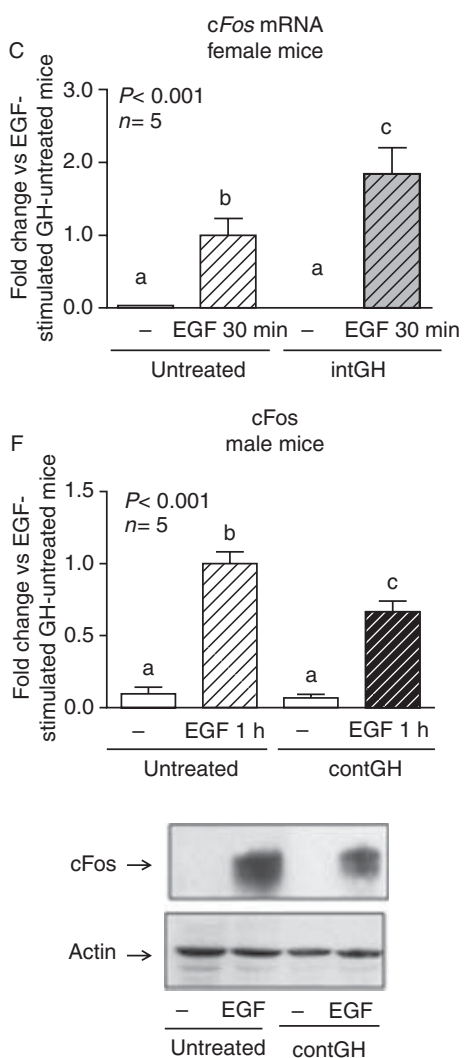

\section{Figure 7}

Hepatic cFos expression and protein content. Liver samples from mice stimulated with EGF during different time periods and their nonstimulated controls were analyzed by qRT-PCR and immunoblotting to determine cFos expression and its protein content induction respectively ( $\mathrm{A}$ and $\mathrm{B}$ ). CFos ( $62 \mathrm{kDa}$ ) expression was analyzed by qRT-PCR in female mice treated with intermittent injections of $\mathrm{GH}$ (intGH), male mice receiving continuous infusion of $\mathrm{GH}$ (contGH), and their respective controls that received acute stimulation with EGF for 30 min (EGF $30 \mathrm{~min}$ ) or not (-) (C and D). Protein content of liver samples was analyzed by immunoblotting in $\mathrm{GH}$-treated and control mice that received acute stimulation with EGF for $1 \mathrm{~h}$ (EGF $1 \mathrm{~h}$ ) or not $(-)(E$ and $F)$. Reprobing with anti-actin antibody demonstrated uniform protein loading for all lanes. Immunoblots were scanned and quantification was performed by densitometry. Results were expressed as fold change vs values measured for EGF-stimulated GH-untreated mice. Data are the mean \pm S.E.M. of the indicated number of subsets $(n)$ of individual animals. Different letters denote significant differences $(P \leq 0.05)$. Representative western blots are shown.

the physiological importance of GH concentration patterns has been extensively described. Actually, GH concentration patterns have differential effects on the hepatic expression of numerous genes (Norstedt \& Palmiter 1984, Waxman et al. 1991, Waxman \& O'Connor 2006) and GH administered in a pulsatile manner induces growth and generation of IGF1 more effectively than continuous administration (Clark \& Robinson 1988, Udy et al. 1997).

Although several studies have been carried out to establish the efficacy of continuous administration of GH, there are not enough studies to determine the security of this treatment compared with intermittent administration of GH. Among the main problems associated with longterm GH treatment is the increased tendency to develop tumors. The expression of the EGFR, broadly involved in http://joe.endocrinology-journals.org DOI: $10.1530 /$ JOE-13-0447
C 2014 Society for Endocrinology Printed in Great Britain 
the pathogenesis of different types of tumors, varies depending on plasma levels of GH. EGFR plays an essential role in the development of not only epithelial cells but also of tumors of epithelial cell origin (Singh \& Harris 2005). Therefore, the objective of this study was to investigate how different GH plasma patterns, induced by different administration protocols, affect EGFR expression, signaling, and induction of mitogenic mediators in the livers of normal mice.

The effects of plasma levels of GH on EGFR expression have been extensively studied. GH administration was found to induce the expression of EGFR in the liver while hypophysectomy reduced the hepatic Egfr mRNA concentration in rats (Ekberg et al. 1989). In accordance, EGFR expression in liver is increased in transgenic mice overexpressing GH but decreased in GH-receptor knockout mice (Miquet et al. 2008, González et al. 2010). However, studies concerning the effects of plasma GH pattern on EGFR expression are still controversial. In rodents, EGFR expression is higher in males than in females as evidenced by specific binding of labeled EGF to purified liver membranes, determination of EGFR mRNA, and immunoblotting from solubilized liver (Ekberg et al. 1989, Johansson et al. 1989, Miquet et al. 2013). Furthermore, in hypophysectomized rats of both sexes, intermittent GH treatment enhanced hepatic Egfr mRNA concentrations compared with levels for normal male rats, while continuous GH administration was less effective or did not have any effects at all (Ekberg et al. 1989, Kashimata et al. 1989). In contrast, other authors found no differences between intermittent and continuous administration of hGH on the induction of Egfr mRNA or EGF binding when administered to hypophysectomized male and female rats (Johansson et al. 1989). Moreover, increased GH levels with a continuous pattern in transgenic mice overexpressing $\mathrm{GH}$ also result from the upregulation of EGFR expression in liver (Miquet et al. 2008, González et al. 2010). These genetically modified mice present high GH levels during the entire lifespan of the animals and many physiological and endocrine alterations may be associated with GH overexpression; therefore, it is difficult to dissect the mechanisms involved in EGFR expression and signaling changes. For this reason, the influence of GH plasma patterns was studied in normal mice supplemented with the hormone for a short period. GH administered by s.c. injections increased hepatic EGFR content in livers of female mice, while continuous administration of the hormone to male mice reduced hepatic receptor mRNA levels and protein content. Therefore, these results support the relevance of the GH concentration pattern as an important determinant of EGFR expression. In accordance, EGFR levels did not change in livers of female mice after continuous administration of GH or in male mice that received intermittent injections of the hormone. As previously discussed for expression of MUPs, EGFR was not significantly induced in male mice that received injections of GH because EGFR liver content is already high due to the endogenous secretion pattern of the hormone. In contrast, a reduction in EGFR levels was not evident in livers of female mice after continuous GH treatment, probably because the receptor content is already low compared with male mice (Miquet et al. 2013).

Continuous elevation of GH plasma levels reduced EGFR protein content and mRNA levels in liver. In contrast, EGFR protein levels were found to be increased in the livers of female mice that received the intermittent treatment with $\mathrm{GH}$, but quantitative RT-PCR of the EGFR showed a tendency to higher levels which were not significantly different from those for control mice. The discrepancy between immunoblotting and quantitative PCR determinations of Egfr might depend on effects of GH on EGFR turnover. GH and prolactin, a protein related to $\mathrm{GH}$, were shown to control the production of EGFR by phosphorylation on serine/threonine residues (Huang et al. 2003, 2004, 2006), which delay EGFR downregulation and therefore potentiate acute EGF-induced signaling (Huang et al. 2003, 2004, 2006, Li et al. 2008). Besides inducing EGFR expression, intermittently administered GH could provoke retardation of EGFR downregulation, thus increasing EGFR protein content to a greater extent than Egfr mRNA levels.

Results from the present study demonstrated that the effects of GH administration on hepatic EGFR content directly correlated with effects on EGF-induced signaling. Such effects were not necessarily the expected results as we had previously observed that transgenic mice overexpressing GH showed an increase in hepatic EGFR content but not in EGF signaling (González et al. 2010). Transgenic mice overexpressing GH display high GH levels throughout their lifespan which trigger several mechanisms to downregulate EGF signalling through the STATs and the PI3K/Akt pathways (González et al. 2010, Díaz et al. 2012). Short-term treatment with GH would not induce such compensatory mechanisms; consequently, changes in EGF signaling were directly correlated with modifications in EGFR liver content.

Considering the role of EGFR in cell proliferation and tumor development, EGF-induced cMYC and cFOS protein and mRNA content were determined. cMYC is a

Published by Bioscientifica Ltd. 
pleiotropic transcription factor that promotes growth and expansion of somatic cells, its activation results in the upregulation of cyclins with concomitant downregulation of cell cycle inhibitors like p21. $c M y c$ is an important proto-oncogene found to be upregulated in many types of cancers (Soucek et al. 2008, Lin et al. 2010). cFOS is a transcription factor that belongs to the family of immediate early genes which is upregulated in response to several mitogenic signals, including EGF (Curran et al. 1985). Increased expression of cFOS has been associated with development of cancer, including hepatocarcinoma (Yuen et al. 2001, Liu et al. 2012). In accordance with the effects of plasma GH pattern on EGF signaling, induction of $c M y c$ was higher in female mice that received intermittent injections of GH compared with untreated animals; and $c M y c$ induction was lowered by continuous GH administration in male mice. Similar results were described when cFos expression and protein content were determined.

In conclusion, a pulsatile GH concentration pattern, produced by intermittent injections of the hormone, induced the upregulation of liver EGFR content, which resulted in an increased response to EGF in female mice, but non-significant effects on EGFR expression and signaling in male mice. In contrast, continuous $\mathrm{GH}$ concentration patterns, induced by sustained administration of the hormone, had no effects on EGFR expression or EGF-induced responses in livers of female mice, but decreased EGFR expression and activation of EGF-induced signaling mediators in male mice, resulting in diminished pro-mitogenic effects. The results indicate the beneficial effects of use of sustained delivery systems that allow continuous GH plasma patterns in terms of treatment security relating to EGFR-mediated protumorogenic adverse effects. Future studies should be carried out in GHD animal models to confirm the benefits of use of those systems for the treatment of GHD-associated states. To extend this conclusion to humans, species differences in GH secretion patterns should be considered and studies on the effects of different plasma GH patterns should be carried out in humans. Moreover, assessment of other GH-regulated proteins such as serum IGF1 and IGFBP3 levels, which have been described as predictors of hepatocarcinoma development, should also be considered in order to determine the potential adverse effects of different administration protocols on tumor promotion.

\section{Supplementary data}

This is linked to the online version of the paper at http://dx.doi.org/10.1530/ JOE-13-0447.

\section{Declaration of interest}

The authors declare that there is no conflict of interest that could be perceived as prejudicing the impartiality of the research reported.

\section{Funding}

Support for these studies was provided by the Consejo Nacional de Investigaciones Científicas Y Técnicas (CONICET) (PIP-427), the Agencia Nacional de Promoción Científica y Tecnológica (ANPCYT) (PICT 2010-0398), and Universidad de Buenos Aires (UBA) (UBACYT 20020090200186). J G M, A I S, M B F, D T, and L G are career investigators of CONICET; M E D and S P R are supported by a fellowship from CONICET; and P E I is supported by a fellowship from UBA.

\section{References}

Biller BM, Ji HJ, Ahn H, Savoy C, Siepl EC, Popovic V, Coculescu M, Roemmler J, Gavrila C, Cook DM et al. 2013 12-Month effects of onceweekly sustained-release growth hormone treatment in adults with $\mathrm{GH}$ deficiency. Pituitary 16 311-318. (doi:10.1007/s11102-012-0422-8)

Buettner R, Mora LB \& Jove R 2002 Activated STAT signaling in human tumors provides novel molecular targets for therapeutic intervention. Clinical Cancer Research 8 945-954.

Burgess AW 2008 EGFR family: structure physiology signaling and therapeutic target. Growth Factors 26 263-274. (doi:10.1080/ 08977190802312844)

Cavaggioni A \& Mucignat-Caretta C 2000 Major urinary proteins, $\alpha(2 \mathrm{U}$-globulins and aphrodisin. Biochimica et Biophysica Acta 1482218 228. (doi:10.1016/S0167-4838(00)00149-7)

Clark RG \& Robinson IC 1988 Paradoxical growth-promoting effects induced by patterned infusions of somatostatin in female rats. Endocrinology 122 2675-2682. (doi:10.1210/endo-122-6-2675)

Curran T, Bravo R \& Müller R 1985 Transient induction of c-fos and c-myc in an immediate consequence of growth factor stimulation. Cancer Surveys 4 655-681.

Díaz ME, González L, Miquet JG, Martínez CS, Sotelo AI, Bartke A \& Turyn D 2012 Growth hormone modulation of EGF-induced PI3K-Akt pathway in mice liver. Cellular Signalling 24 514-523. (doi:10.1016/ j.cellsig.2011.10.001)

Ekberg S, Carlsson L, Carlsson B, Billig H \& Jansson JO 1989 Plasma growth hormone pattern regulates epidermal growth factor (EGF) receptor messenger ribonucleic acid levels and EGF binding in the rat liver. Endocrinology 125 2158-2166. (doi:10.1210/endo-125-4-2158)

Fresno Vara JA, Casado E, de Castro J, Cejas P, Belda-Iniesta C \& González-Barón M 2004 PI3K/Akt signalling pathway and cancer. Cancer Treatment Reviews 30 193-204. (doi:10.1016/j.ctrv.2003.07.007)

Frungieri MB, Weidinger S, Meineke V, Kohn FM \& Mayerhofer A 2002 Proliferative action of mast-cell tryptase is mediated by PAR2, COX2, prostaglandins, and PPAR $\gamma$ : possible relevance to human fibrotic disorders. PNAS 99 15072-15077. (doi:10.1073/pnas.232422999)

González L, Díaz ME, Miquet JG, Sotelo AI, Fernández D, Dominici FP, Bartke A \& Turyn D 2010 GH modulates hepatic epidermal growth factor signaling in the mouse. Journal of Endocrinology 204 299-309. (doi:10.1677/JOE-09-0372)

Guren TK, Odegard J, Abrahamsen H, Thoresen GH, Susa M, Andersson Y, Østby E \& Christoffersen T 2003 EGF receptor-mediated, c-Srcdependent, activation of Stat5b is downregulated in mitogenically responsive hepatocytes. Journal of Cellular Physiology 196 113-123. (doi:10.1002/jcp.10282)

Henson ES \& Gibson SB 2006 Surviving cell death through epidermal growth factor (EGF) signal transduction pathways: implications for cancer therapy. Cellular Signalling 12 2089-2097. (doi:10.1016/j.cellsig. 2006.05.015)

Published by Bioscientifica Ltd. 
Herrington J \& Carter-Su C 2001 Signaling pathways activated by the growth hormone receptor. Trends in Endocrinology and Metabolism 12 252-257. (doi:10.1016/S1043-2760(01)00423-4)

Huang Y, Kim SO, Jiang J \& Frank SJ 2003 Growth hormone-induced phosphorylation of epidermal growth factor (EGF) receptor in 3T3-F442A cells. Modulation of EGF-induced trafficking and signaling. Journal of Biological Chemistry 278 18902-18913. (doi:10.1074/jbc. M300939200)

Huang Y, Chang Y, Wang X, Jiang J \& Frank SJ 2004 Growth hormone alters epidermal growth factor receptor binding affinity via activation of extracellular signal-regulated kinases in 3T3-F442A cells. Endocrinology 145 3297-3306. (doi:10.1210/en.2003-1658)

Huang Y, Li X, Jiang J \& Frank SJ 2006 Prolactin modulates phosphorylation, signaling and trafficking of epidermal growth factor receptor in human T47D breast cancer cells. Oncogene 25 7565-7576. (doi:10.1038/ sj.onc.1209740)

Ito Y, Takeda T, Sakon M, Tsujimoto M, Higashiyama S, Noda K, Miyoshi E, Monden M \& Matsuura N 2001 Expression and clinical significance of erb-B receptor family in hepatocellular carcinoma. British Journal of Cancer 84 1377-1383. (doi:10.1054/bjoc.2000.1580)

Jaffe CA, Ocampo-Lim B, Guo W, Krueger K, Sugahara I, DeMott-Friberg R, Bermann M \& Barkan AL 1998 Regulatory mechanisms of growth hormone secretion are sexually dimorphic. Journal of Clinical Investigation 102 153-164. (doi:10.1172/JCI2908)

Jaffe CA, Turgeon DK, Lown K, Demott-Friberg R \& Watkins PB 2002 Growth hormone secretion pattern is an independent regulator of growth hormone actions in humans. American Journal of Physiology. Endocrinology and Metabolism 283 1008-1015. (doi:10.1152/ajpendo. 00513.2001)

Jansson JO, Edén S \& Isaksson O 1985 Sexual dimorphism in the control of growth hormone secretion. Endocrine Reviews 6 128-150. (doi:10.1210/ edrv-6-2-128)

Jansson JO, Ekberg S, Hoath SB, Beamer WG \& Frohman LA 1988 Growth hormone enhances hepatic epidermal growth factor receptor concentration in mice. Journal of Clinical Investigation 82 1871-1876. (doi:10.1172/JCI113804)

Jenkins PJ 2006 Cancers associated with acromegaly. Neuroendocrinology $\mathbf{8 3}$ 218-223. (doi:10.1159/000095531)

Johansson S, Husman B, Norstedt G \& Andersson G 1989 Growth hormone regulates the rodent hepatic epidermal growth factor receptor at a pretranslational level. Journal of Molecular Endocrinology 3 113-120. (doi:10.1677/jme.0.0030113)

Johansson JO, Oscarsson J, Bjarnason R \& Bengtsson BA 1996 Two weeks of daily injections and continuous infusion of recombinant human growth hormone (GH) in GH-deficient adults: I. Effects on insulin-like growth factor-I (IGF-I), GH and IGF binding proteins, and glucose homeostasis. Metabolism 45 362-369. (doi:10.1016/S00260495(96)90292-9)

Johnson D, al-Shawi R \& Bishop JO 1995 Sexual dimorphism and growth hormone induction of murine pheromone-binding proteins. Journal of Molecular Endocrinology 14 21-34. (doi:10.1677/jme.0.0140021)

Karlsson H, Gustafsson JA \& Mode A 1999 Cis desensitizes GH induced Stat5 signaling in rat liver cells. Molecular and Cellular Endocrinology 154 37-43. (doi:10.1016/S0303-7207(99)00101-X)

Kashimata M, Hiramatsu M \& Minami N 1989 Differential secretory rhythm of growth hormone controls the number of hepatic epidermal growth factor receptors in the rat. Journal of Endocrinology 123 75-81. (doi:10.1677/joe.0.1230075)

Kemp SF \& Frindik JP 2011 Emerging options in growth hormone therapy: an update. Drug Design, Development and Therapy 5 411-419. (doi:10.2147/DDDT.S23140)

Kwak HH, Shim WS, Choi MK, Son MK, Kim YJ, Yang HC, Kim TH, Lee GI, Kim BM, Kang SH et al. 2009 Development of a sustained-release recombinant human growth hormone formulation. Journal of Controlled Release 137 160-165. (doi:10.1016/j.jconrel.2009.03.014)

http://joe.endocrinology-journals.org DOI: $10.1530 /$ JOE-13-0447
(C) 2014 Society for Endocrinology Printed in Great Britain
Laron Z 2011 Growth hormone therapy: emerging dilemmas. Pediatric Endocrinology Reviews 8 364-373.

Laursen T, Gravholt CH, Heickendorff L, Drustrup J, Kappelgaard AM, Jørgensen JO \& Christiansen JS 2001 Long-term effects of continuous subcutaneous infusion versus daily subcutaneous injections of growth hormone $(\mathrm{GH})$ on the insulin-like growth factor system, insulin sensitivity, body composition, and bone and lipoprotein metabolism in GH-deficient adults. Journal of Clinical Endocrinology and Metabolism 86 1222-1228. (doi:10.1210/jcem.86.3.73)

Li X, Huang Y, Jiang J \& Frank SJ 2008 ERK-dependent threonine phosphorylation of EGF receptor modulates receptor downregulation and signaling. Cellular Signalling 20 2145-2155. (doi:10.1016/j.cellsig. 2008.08.006)

Lin CP, Liu CR, Lee CN, Chan TS \& Liu HE 2010 Targeting c-Myc as a novel approach for hepatocellular carcinoma. World Journal of Hepatology 2 16-20. (doi:10.4254/wjh.v2.i1.16)

Liu Z, Yan R, Al-Salman A, Shen Y, Bu Y, Ma J, Luo DX, Huang C, Jiang Y, Wilber A et al. 2012 Epidermal growth factor induces tumour marker AKR1B10 expression through activator protein-1 signalling in hepatocellular carcinoma cells. Biochemical Journal 442 273-282. (doi:10.1042/ BJ20111322)

MacLeod JN, Pampori NA \& Shapiro BH 1991 Sex differences in the ultradian pattern of plasma growth hormone concentrations in mice. Endocrinology 131 395-399. (doi:10.1677/joe.0.1310395)

Miquet JG, González L, Matos MN, Hansen C, Louis A, Bartke A, Turyn D \& Sotelo AI 2008 Transgenic mice overexpressing GH exhibit hepatic upregulation of GH-signaling mediators involved in cell proliferation. Journal of Endocrinology 198 317-330. (doi:10.1677/JOE-08-0002)

Miquet JG, Freund T, Martinez CS, González L, Diaz ME, Micucci GP, Zotta E, Boparai RK, Bartke A, Turyn D et al. 2013 Hepatocellular alterations and dysregulation of oncogenic pathways in the liver of transgenic mice overexpressing growth hormone. Cell Cycle $\mathbf{1 2}$ 1042-1057. (doi:10.4161/cc.24026)

Normanno N, De Luca A, Bianco C, Strizzi L, Mancino M, Maiello MR, Carotenuto A, De Feo G, Caponigro F \& Salomon DS 2006 Epidermal growth factor receptor (EGFR) signaling in cancer. Gene 366 2-16. (doi:10.1016/j.gene.2005.10.018)

Norstedt G \& Palmiter R 1984 Secretory rhythm of growth hormone regulates sexual differentiation of mouse liver. Cell 36 805-812. (doi:10.1016/0092-8674(84)90030-8)

Osaki M, Oshimura M \& Ito H 2004 PI3K-Akt pathway: its functions and alterations in human cancer. Apoptosis 9 667-676. (doi:10.1023/ B:APPT.0000045801.15585.dd)

Park MR, Seo BB \& Song SC 2013 Dual ionic interaction system based on polyelectrolyte complex and ionic, injectable, and thermosensitive hydrogel for sustained release of human growth hormone. Biomaterials 34 1327-1336. (doi:10.1016/j.biomaterials.2012.10.033)

Péter F, Bidlingmaier M, Savoy C, Ji HJ \& Saenger PH 2012 Three-year efficacy and safety of LB03002, a once-weekly sustained-release growth hormone (GH) preparation, in prepubertal children with GH deficiency (GHD). Journal of Clinical Endocrinology and Metabolism 97 400-407. (doi:10.1210/jc.2011-2234)

Pfaffl MW 2001 A new mathematical model for relative quantification in realtime RT-PCR. Nucleic Acids Research 29 e45. (doi:10.1093/nar/ 29.9.e45)

Quesnelle KM, Boehm AL \& Grandis JR 2007 STAT mediated EGFR signaling in cancer. Journal of Cellular Biochemistry 102 311-319. (doi:10.1002/jcb.21475)

Ram PA \& Waxman DJ 2000 Role of the cytokine-inducible SH2 protein CIS in desensitization of STAT5b signaling by continuous growth hormone. Journal of Biological Chemistry 275 39487-39496. (doi:10.1074/ jbc.M004755200)

Riese DJ II \& Stern DF 1998 Specificity within the EGF family/ErbB receptor family signaling network. BioEssays: News and Reviews in Molecular Cellular and Developmental Biology 20 41-48. (doi:10.1002/(SICI)15211878(199801)20:1 < 41::AID-BIES7 > 3.0.CO;2-V) 
Singh AB \& Harris RC 2005 Autocrine, paracrine and juxtacrine signaling by EGFR ligands. Cellular Signalling 17 1183-1193. (doi:10.1016/ j.cellsig.2005.03.026)

Siobhan L \& Shereen E 2008 Acromegaly: re-thinking the cancer risk. Reviews in Endocrine \& Metabolic Disorders 9 41-58. (doi:10.1007/ s11154-007-9063-z)

Soucek L, Whitfield J, Martins CP, Finch AJ, Murphy DJ, Sodir NM, Karnezis AN, Swigart LB, Nasi S \& Evan GI 2008 Modelling Myc inhibition as a cancer therapy. Nature 455 679-683. (doi:10.1038/nature07260)

Udy GB, Towers RP, Snell RG, Wilkins RJ, Park SH, Ram PA, Waxman DJ \& Davey HW 1997 Requirement of STAT5b for sexual dimorphism of body growth rates and liver gene expression. PNAS 94 7239-7244. (doi:10.1073/pnas.94.14.7239)

Veldhuis JD \& Bowers CY 2003 Human GH pulsatility: an ensemble property regulated by age and gender. Journal of Endocrinological Investigation 26 799-813. (doi:10.1007/BF03345229)
Waxman DJ \& O'Connor C 2006 Growth hormone regulation of sex-dependent liver gene expression. Molecular Endocrinology 20 2613-2629. (doi:10.1210/me.2006-0007)

Waxman DJ, Pampori NA, Ram PA, Agrawal AK \& Shapiro BH 1991 Interpulse interval in circulating growth hormone patterns regulates sexually dimorphic expression of hepatic cytochrome P450. PNAS 88 6868-6872. (doi:10.1073/pnas.88.15.6868)

Wei Y, Wang Y, Kang A, Wang W, Ho SV, Gao J, Ma G \& Su Z 2012 A novel sustained-release formulation of recombinant human growth hormone and its pharmacokinetic, pharmacodynamic and safety profiles. Molecular Pharmaceutics 9 2039-2048. (doi:10.1021/mp300126t)

Wells A 1999 EGF receptor. International Journal of Biochemistry \& Cell Biology 31 637-643. (doi:10.1016/S1357-2725(99)00015-1)

Yuen MF, Wu PC, Lai VC, Lau JY \& Lai CL 2001 Expression of c-Myc, c-Fos, and c-Jun in hepatocellular carcinoma. Cancer 91 106-112. (doi:10. 1002/1097-0142(20010101)91:1<106::AID-CNCR14>3.0.CO;2-2)

Received in final form 3 February 2014

Accepted 10 March 2014

Accepted Preprint published online 12 March 2014
C 2014 Society for Endocrinology Printed in Great Britain
Published by Bioscientifica Ltd. 